\title{
HUBUNGAN POLA ASUH ORANG TUA DENGAN STATUS GIZI BALITA
}

\author{
The Relationship Of Parents' Parenting Patterns With Nutritional Status To Children
}

\author{
Sulaeman $^{1}$, Basra $^{2}$, Murtini $^{3}$, Kassaming $^{4}$, Hamdiyah $^{5}$ \\ 1,2,3,4,5 Program Studi Ilmu Keperawatan Institut Teknologi Kesehatan dan Sains Muhammadiyah Sidrap
}

\author{
Alamat Korespondensi : Jl. Syarif Al Qadri No.11 Pangkajene \\ Kabupaten Sidrap \\ E-mail: sulaemansidrap92@gmail.com
}

\begin{abstract}
ABSTRAK
Pola Asuh orang tua merupakan peran utama dalam pertumbuhan pada masa balita, Gizi adalah segala sesuatu yang dikonsumsi oleh manusia yang mengandung unsur-unsur zat gizi yaitu karbohidrat, vitamin, mineral, lemak, protein dan air yang digunakan untuk mempertahankan kehidupan, pertumbuhan dan perkembangan dari organ-organ tubuh manusia. Penelitian ini bertujuan untuk mengetahui hubungan pola asuh orang dengan status gizi balita di Wilayah Kerja Puskesmas Kulo Tahun 2020. Desain penelitian yang digunakan adalah kuantitatif, dengan metode Deskriptif Analitik dengan pendekatan Cross sectional dimana peneliti mengukur variabel secara bersama dan hasil yang diperoleh menggambarkan kondisi yang terjadi saat penelitian dilakukan. Populasi penelitian adalah orang tua yang memiliki balita di Wilayah Kerja Puskesmas Kulo tahun 2020 dan tehnik pengambilan sampel dengan cara Purposive Sampling. Penelitian menggunakan uji Pearson Chi-Square, didapatkan ada hubungan pola asuh orang tua dengan status gizi balita di Wilayah Kerja Puskesmas Tahun $2020(p=0,002)$.
\end{abstract}

Kata kunci : Pola Asuh, Status Gizi Balita

\begin{abstract}
Parenting is a major role in growth in toddlerhood, nutrition is everything that is consumed by humans that contains elements of nutrients, namely carbohydrates, vitamins, minerals, fats, proteins and water used to maintain life, growth and development of children. human organs. This study aims to determine the relationship between parenting patterns and the nutritional status of children under five in the Kulo Health Center Work Area in 2020. The research design used was quantitative, with an analytical descriptive method with a cross sectional approach where researchers measured variables together and the results obtained described the conditions that occurred. when the research was conducted. The research population is parents who have toddlers in the Kulo Health Center Work Area in 2020 and the sampling technique is purposive sampling. The study used the Pearson Chi-Square test, it was found that there was a relationship between parenting patterns and the nutritional status of children under five in the Health Center Work Area in $2020(p=0.002)$.
\end{abstract}

Keywords : Parenting Patterns, Nutritional Status of Toddlers

\section{PENDAHULUAN}

Masa balita sering disebut dengan masa keemasan dimana masa balita berlangsung sangat pendek dan tidak dapat diulangi lagi masa ini anak mudah sakit dan mudah terjadi kekurangan gizi (Putri, 2018).
Status gizi yang tidak cukup menyebabkan retradasi pertumbuhan pada anak dalam pemenuhan kebutuhan dapat berupa nutrisi agar sesuai dengan tumbuh kembang anak selain itu kebutuhan fisik serta bimbingan dan kasih sayang orang tua dalam 
mengasuh anak menjadi salah satu faktor yang berperan penting dalam pengasuhan anak (Manumbalang, Rompas, \& Bataha, 2017).

Pola asuh memegang peranan penting dalam terjadinya gangguan pertumbuhan tumbuh kembang pada balita terdapat 3 faktor yang berperan penting dalam pertumbuhan balita (makanan, kesehatan, kebersihan) (Pratiwi, Masrul, \& Yerizel, 2016). Di masa yang akan datang masa depan anak akan sangat tergantung dari pengalaman yang didapatkan anak termasuk pola asuh orang tua (Manumbalang, Rompas, \& Bataha, 2017).

Menurut Kemenkes RI pada tahun 2018 menurut karakteristik prevalensi status gizi $(\mathrm{BB} / \mathrm{U})$ pada anak umur 0-59 bulan (balita) gizi kurang menurut umur 0-5 $(8,1 \%) \quad 6-11 \quad(9,2 \%) \quad 12-23(14,1 \%) \quad 24-35$ (16,2\%), 36-47 (15,5\%), 48-59 (14,5\%) dan prevalensi gizi baik menurut umur 0-5 $(85,1 \%) \quad 6-11(85,2 \%)$ 12-23 (78,9\%) 24-35 $(76,4 \%), \quad 36-47 \quad(77,6 \%), \quad 48-59 \quad(78,0 \%)$ sedangkan untuk prevalenzi jenis kelamin gizi kurang laki laki $(14,3 \%)$ gizi baik $(78,1 \%)$ dan jenis kelamin perempuan gizi kurang perempuan $(13,3 \%)$ gizi baik $(80,3 \%)$. prevalensi status gizi $(\mathrm{BB} / \mathrm{U})$ pada anak umur 0-59 bulan (balita) tertinggi pada Provinsi Nusa Nenggara Timur gizi kurang tertinggi (22.2\%) dan Provinsi Kepulauan Riau terendah $(9,8 \%)$ sedangkan untuk wilayah Sulawesi Selatan sebanyak $(18,4 \%)$ dan Provinsi Jawa Barat gizi baik tertinggi $(84,3 \%)$ dan Provinsi Nusa Tenggara Timur terendah $(69,3 \%)$ dan wilayah Sulawesi
Selatan $(74,2 \%)$ dan berdasarkan TB/U tertinggi pada Provinsi Nusa Tenggara Timur pendek sebanyak (26,7\%) kepulauan DKI Jakarta terendah $(11,5 \%)$ dan Sulawesi Selatan $(23.2 \%)$ sedangkan prevalansi status gizi berdasarkan $(\mathrm{BB} / \mathrm{TB})$ tertinggi pada Provinsi Gorontalo kurus sebanyak (10,6\%) Kepulauan Bali terendah sebanyak (4,4\%) wilayah Sulawesi Selatan $(7,5 \%)$ (Kemenkes RI, 2018 ).

Berdasarkan hasil observasi dari wawancara di Wilayah Kerja Puskesmas Kulo jumlah balita yang ditimbang dari bulan Januari - Desember 2016-2019 sebanyak 1.104 balita dan angka kejadian balita gizi kurang didapatkan dari bulan Januari - Desember 2019 sebanyak 44 balita yang mengalami gizi kurang, Adapun beberapa hal yang diprioritaskan dan diperhatikan paling utama pada status gizi dikarenakan oleh penyakit infeksi, pola asuh yang terkait pada asupan gizi makanan, kebersihan dan kesehatan faktor pendidikan serta sosial ekonomi. Ada ibu yang menyatakan bahwa anaknya susah makan dan mereka tidak memahami kebutuhan zat gizi nutrisi untuk pertumbuhan anakanya, ibu sering memberikan makanan yang disukai anaknya saja tanpa memperhatiakn zat gizi yang ada didalam kandungan makanaanya. Sehingga peneliti tertarik untuk melakukan penelitian hubungan pola asuh orang tua dengan status gizi balita di Wilayah Kerja Puskesmas Kulo Kabupaten Sidenreng Rappang tahun 2020. 
Berdasarkan uraian diatas, peneliti tertarik menganalisis hubungan pola asuh orang tua dengan status gizi balita.

Adapun tujuan penelitian untuk mengetahui hubungan pola asuh ibu dengan status gizi balita di Wilayah Kerja Puskesmas Kulo Kabupaten Sidenreng Rappang tahun 2020.

\section{METODE}

Desaian penelitian yang digunakan adalah kuantitatif, dengan metode Deskriptif Analitik dengan pendekatan Cross sectional dimana peneliti mengukur variabel secara bersama dan hasil yang diperoleh menggambarkan kondisi yang terjadi saat penelitian dilakukan.

Lokasi penelitian ini dilaksanakan di Wilayah Kerja Puskesmas Kulo Kabupaten Sidenreng Rappang. Adapaun waktu penelitian 15 Juni s/d 30 Juli 2020.

Populasi penelitian adalah orang tua yang memiliki balita di Wilayah Kerja Puskesmas Kulo tahun 2020 dan tehnik pengambilan sampel dengan cara Purposive Sampling.

Instrumen penelitian dalam pengumpulan data dilakukan dengan cara membagikan kuesioner kepada responden. Kuesioner yang terkumpul dan diisi akan diperiksa kembali untuk menghindari dan memperbaiki kesalahan yang mungkin terjadi pada saat pengisian. Setelah pemeriksaan kuesioner dilakukan, langkah selanjutnya adalah entri data, pengolahan data, dan dianalisa.
Metode analisis data dengan menggunakan metode analisis univariat dan analisis bivariat. Uji analisi univariat dilakukan terhadap variabel-variabel dari hasil penelitian. Analisis ini mengahasilkan distribusi dan presentasi dari tiap-tiap variabel sedangkan analisis bivariat dilakukan untuk melihat hubungan antara varibel bebas dan varibel terkait. Hasil analisis dengan menggunakan uji Pearson Chi-square.

\section{HASIL DAN PEMBAHASAN}

\section{Data Umum}

Tabel 1. Distribusi frekuensi karakteristik Ibu dan Balita di Wilayah Kerja Puskesmas Kulo Tahun 2020

\begin{tabular}{llcc}
\hline $\begin{array}{l}\text { Karakteristik } \\
\text { Balita }\end{array}$ & Ibu dan & $\mathbf{N}$ & \% \\
\hline Umur Ibu & $25-29$ tahun & 21 & 70 \\
\cline { 2 - 4 } & $30-35$ tahun & 9 & 30 \\
\hline & 1 tahun & 2 & 6,7 \\
\cline { 2 - 4 } Umur & 2 tahun & 8 & 26,7 \\
\cline { 2 - 4 } \begin{tabular}{lcc} 
Balita \\
\cline { 2 - 4 }
\end{tabular} & 3 tahun & 13 & 43,3 \\
\hline Jenis & 4 tahun & 7 & 23,3 \\
Kelamin & Laki-Laki & 4 & 33,3 \\
\cline { 2 - 4 } Balita & Perempuan & 11 & 66,7 \\
\hline Total & & 30 & 100 \\
\hline Sumber & Data Primer 2020 & &
\end{tabular}

Sumber : Data Primer 2020

Berdasarkan tabel 1 menunjukkan mayoritas umur ibu berusia 25-29 tahun (70\%), umur balita sebagian besar berusia 3 tahun $(43,3 \%)$, sedangkan jenis kelamin balita mayoritas adalah perempuan $(66,7 \%)$. 


\section{Data Khusus}

a. Pola Asuh

Tabel 2. Distribusi Responden Berdasarkan Pola Asuh di Wilayah Kerja Puskesmas Kulo Tahun 2020

\begin{tabular}{lcc}
\hline Pola Asuh & N & \% \\
\hline Baik & 26 & 86,7 \\
\hline Kurang & 4 & 13,3 \\
\hline Total & 30 & 100 \\
\hline
\end{tabular}

Sumber : Data Primer 2020

Berdasarkan tabel 2 menunjukkan bahwa dari 30 responden mayoritas pola asuh baik sebanyak 26 orang $(86,7 \%)$, sedangkan minoritas pola asuh kurang sebanyak 4 orang $(13,3 \%)$.

\section{b. Status Gizi Balita}

Tabel 3. Distribusi Responden Berdasarkan Status Gizi di Wilayah Kerja Puskesmas Kulo Tahun 2020

\begin{tabular}{lcc}
\hline Status Gizi & $\mathbf{N}$ & $\mathbf{\%}$ \\
\hline Kurang & 1 & 3,3 \\
\hline Sedang & 9 & 30 \\
\hline Baik & 20 & 66,7 \\
\hline Total & 30 & 100
\end{tabular}

Sumber : Data Primer 2020

Berdasarkan Tabel 3 menunjukkan bahwa dari 30 balita yang mayoritas berstatus gizi baik sebanyak 20 orang (66,7\%), sedangkan minoritas yang berstatus gizi kurang sebanyak 1 orang $(3,3 \%)$.

3. Hubungan antara pola asuh ibu dengan status gizi balita di Wilayah Kerja Puskesmas Kulo

Tabel 4. Tabulasi Silang Hubungan Antara Pola Asuh Ibu Dengan Status Gizi Balita di Wilayah Keja Puskesmas Kulo Tahun 2020

\begin{tabular}{lcccccccc}
\hline Pola & \multicolumn{4}{c}{ Status Gizi } & & \multicolumn{3}{c}{ Total } \\
\cline { 2 - 6 } Asuh & \multicolumn{1}{c}{ Kurang } & Sedang & \multicolumn{2}{c}{ Baik } & & & \\
\hline & $\mathbf{N}$ & $\%$ & $\mathbf{N}$ & $\%$ & $\mathbf{N}$ & $\mathbf{\%}$ & $\mathbf{N}$ & $\mathbf{\%}$ \\
& & & & & & & & \\
\hline Baik & 0 & 0 & 6 & 20,0 & 20 & 66,7 & 26 & 86,7 \\
\hline Kurang & 1 & 3,3 & 3 & 10,0 & 0 & 0 & 4 & 13,3 \\
\hline Total & 1 & 3,3 & 9 & 30,0 & 20 & 66,7 & 30 & 100 \\
\hline
\end{tabular}

Pearson Chi-square $\mathrm{P}=0,002(<0,05)$

Berdasarkan tabel 4, diperoleh data bahwa hasil penelitian dari 30 responden menunjukkan bahwa responden yang memiliki pola asuh baik dengan status gizi baik sebanyak 20 orang $(66,7 \%)$, dan pola asuh baik dengan status gizi sedang sebanyak 6 orang $(20,0 \%)$, sedangkan yang memiliki pola asuh kurang dengan status gizi sedang sebanyak 3 orang $(10,0 \%)$, dan pola asuh kurang dengan status gizi kurang sebanyak 1 orang $(3,3 \%)$.

Analisis menggunakan uji statistic Pearson Chi-square di peroleh $\mathrm{p}=0,002$ karna nilai $\mathrm{p}<0,05$ artinya Ho ditolak dan $\mathrm{Ha}$ diterima, hal ini menunjukkan bahwa ada hubungan bermakna antara pola asuh orang tua dengan status gizi balita di Wilayak Kerja Puskesma Kulo Tahun 2020.

Hasil penelitian ini sejalan dengan penelitian Mona Rahayu Putri (2018) dengan judul hubungan antara pola asuh orang tua dengan status gizi balita di Wilayah Kerja Puskesmas Bulang Kota Batam didapatkan hasil uji statistik Chi-Square dengan menggunakan program dan SPSS versi 18 diperoleh nilai $p$ sebesar 0,009 sehingga $\mathrm{p}<$ 0,05 berarti hipotesa diterima dengan kesimpulan ada hubungan antara pola asuh orang tua dengan status gizi Balita di 
Wilayah Kerja Puskesmas Bulang Kota Batam.

Hasil penelitian ini juga sejalan dengan penelitian (Vicka dkk, 2014) dengan judul "Hubungan Pola Asuh Ibu dengan Status Gizi Balita di Wilayah Kerja Puskesmas Ranotana Weru Kecamatan Wanea Kota Manado" didapatkan hasil uji statistik Chi-Square nilai $p$ sebesar $0,001<$ $\alpha=0,05$ yang berarti Ho ditolak, yaitu terdapat hubungan antara pola asuh ibu dengan status gizi balita di Wilayah Kerja Puskesmas Ranotana Weru Kecamatan Wanea Kota Manado. Pola asuh yang baik, menghasilkan status gizi yang baik.

Hasil penelitian ini juga sejalan dengan penelitian yang dilakukan Hasil penelitian (Munawaroh, 2015) dengan judul “. Pola Asuh Mempengaruhi Status Gizi Balita". Semakin baik pola asuh yang diberikan maka semakin baik status gizi balita dan sebaliknya apabila ibu memberikan pola asuh yang kurang baik pada balita maka status gizi balita juga akan terganggu.

Penelitian ini juga sejalan dengan penelitian Ariska Putri H, 2017 dengan judul "Hubungan Pola Asuh Orang Tua Dengan Status Gizi Pada Balita usia $1-5$ tahun di desa Selokgondang Kecamatan Sukodono Kabupaten Lumajang.”

Menurut asumsi peneliti pola asuh orang tua merupahkan pola asuh yang paling dibutuhkan pada masa balita dimana pola asuh orang tua berpengaruh terhadap status gizi baik pada balita bahwa dengan gaya pengasuhan yang baik/tepat, anak dapat berkembang sesuai dengan pertumbuhan dan perkembanganya.

\section{PENUTUP}

Berdasarkan penelitian dan pembahasan serta tujuan dari penelitian maka dapat disimpulkan bahwa terdapat hubungan antara pola asuh ibu dengan status gizi balita di Wilayah Kerja Puskesmas Kulo Kabupaten Sidenreng Rappang tahun 2020.. Pola asuh yang baik, menghasilkan status gizi yang baik. Semakin baik pola asuh yang diberikan maka semakin baik status gizi balita dan sebaliknya apabila ibu memberikan pola asuh yang kurang baik pada balita maka status gizi balita juga akan terganggu.

\section{DAFTAR PUSTAKA}

Kemenkes RI, 2018 Badan pengembangan kesehatan. Prevalensi .

Manumbalang, S., Trophina, Rompas, S., \& B, B. Y. (2017). Hubungan Pola Asuh Dengan Status Gizi Pada Anak Di Taman Kanak-Kanak Kecamatan Pulutan Kabupaten Talaud. E-Journal Keperawatan, 5 Nomor 2, 1-8.

Munawaroh 2015, PolaAsuh Mempengaruhi Status Gizi Balita.

Pratiwi, T. D., Yerizel, E., \& Masrul. (2016). Hubungan Pola Asuh Ibu Denga Status Gizi Balita Di Wilayah Kerja Puskesmas Belimbing Kota Padang. Jurnal Kesehatan Andalas, 5(3), 661665. Retrieved from http://jurnal.fk.unand.ac.id

Putri, M. R. (2018). Hubungan Pola Asuh Orang Tua Dengan Status GiziPada Balita Di Wilayah Kerja Puskesmas Bulang Kota Batam. Jurnal Bidan Komunitas, II(2), 107-116. Retrieved fromhttp://ejournal.hevetia.ac.id/ip/jbk. 
Pratiwi, 2018, Hubungan Pola Asuh Ibu dengan Status Gizi Anak Balita Di Wilayah Kerja puskesmas Pantai Cermin.pdf diakses 25 Maret 2018

Vicka dkk, 2014 Hubungan Pola Asuh Ibu dengan Status Gizi Balita di Wilayah Kerja Puskesmas Ranotana Weru Kecamatan Wanea Kota Manado. 